\title{
Effects of Light Intensity, Illumination Cycles on Microalgae Haematococcus Pluvialis for Production of Astaxanthin
}

\author{
Y. K. Wong*, Y. H. Ho, K. C. Ho, Y. T. Lai, P. M. Tsang, K. P. Chow, Y. H. Yau, M. C. Choi, R. S. C. \\ Ho
}

Centre for Research in Environmental Science, School of Science and Technology, The Open University of Hong Kong, HKSAR, China

*Corresponding author: Y.K. Wong, Centre for Research in Environmental Science, School of Science and Technology, The Open University of Hong Kong, Hong Kong, E-mail: yekwong@ouhk.edu.hk

\begin{abstract}
Microalgae Haematococcus pluvialis was reported as one of the major producers of astaxanthin. Light stress was applied to enhance the astaxanthin content in H. pluvialis. H. pluvialis was cultivated in BG-11 medium for 12 days under irradiation of white plasma light, blue LED light and red LED light. Two-stage cultivation was applied by exposing $H$. pluvialis under low light intensity first, then further to nitrogen starvation and high light intensity for 3 days. The results of green stage indicated that white plasma with 24:0 light/dark (L/D) cycle was the best condition for cell growth with maximum cell density $\left(8.58 \pm 0.452 \times 10^{5}\right.$ cells $\left./ \mathrm{ml}\right)$ and specific growth rate $\left(0.365 \pm 0.004\right.$ day $\left.^{-1}\right)$. After 3 -day stress condition with high light intensity and nitrogen starvation, white plasma with $24: 0 \mathrm{~L} / \mathrm{D}$ cycle was the best condition for lipid $(0.055 \pm 0.002 \mathrm{~g} / \mathrm{L})$ and astaxanthin production $(0.049 \pm 0.001 \mathrm{~g} / \mathrm{L})$. The lowest production cost for producing $1 \mathrm{~g}$ of lipid and astaxanthin was under red LED light with 24:0 L/D cycle.
\end{abstract}

Keywords: Haematococcus pluvialis; Astaxanthin; Lighting; Light/dark cycle; Biomass production; Lipid production; Production cost
Received date: September 01, 2016

Accepted date: November 16, 2016

Published date: November 24, 2016

Citation: Wong Y.K., et al. Effects of Light Intensity, Illumination Cycles on Microalgae Haematococcus Pluvialis for Production of Astaxanthin. (2016) J Marine Biol Aquacult 2(2): 1- 6 .

DOI: $10.15436 / 2381-0750.16 .1083$

\section{Introduction}

Astaxanthin (a keto-carotenoid, belonging to a class of compounds known as terpenes (3S-3'S)-dihydroxy- $\beta, \beta$-carotene-4, 4'-dione) is a substance responsible for the red color which emerge when cooked in salmon, lobsters, seashell and other crustaceans. Astaxanthin has been used not only as a fish feed in aquaculture, but also as a valuable supplement for human. Astaxanthin has a high market price owing to its powerful property of free radical quenching (Lorenz \& Cysewski, 2000). Its benefit as a strong antioxidant is even greater than $\beta$-carotene, zeaxanthin, canthaxanthin, vitamin $\mathrm{C}$ and $\alpha$-tocopherol (Lorenz \& Cysewski, 2000; Miki, 1991). Although astaxanthin can be synthesized artificially, natural astaxanthin is over 20 times stronger in free radical elimination (Capelli et al., 2013). Astaxanthin is found naturally in microalgae, yeasts, fungi and shrimps, especially arctic krill that provides red colour if fishes are fed on these plankton. H. pluvialis the microalgae rich in astaxanthin esters that is similar to crustacean, and have been used as the main production of keto-carotenoid astaxanthin (Orosa et al., 2001).

To produce higher amounts of astaxanthin content in microalgae, physical and chemical factors have been reported as the major factors influencing the growth and formation of astaxanthin. These factors include light intensity, temperature, salinity, nitrogen and phosphorus content in culture (Borowitzka et al., 1991; Boussiba \& Vonshak, 1991; Fábregas et al., 2001; Sarada, Tripathi \& Ravishankar, 2002; Tripathi et al., 2002). Boussiba (2000) claimed that large amount of astaxanthin was present in the resting cells and accumulated rapidly under bright light, high salinity and nutrient deprivation (nitrogen and phosphorous). Furthermore, light cycles can be adjusted to optimize the cell 
growth and astaxanthin accumulation (Domínguez-Bocanegra et al., 2007). Giannelli et al. (2015) reported that requirement of light for optimal astaxanthin synthesis has to be differentiated between cell growth stage and astaxanthin accumulation stage. To accumulate higher amount of astaxanthin, the first stage is using low light intensity to promote $H$. pluvialis growth until the optimal cell density is reached. In later stage, high radiance is used as a stress condition to induce the accumulation of secondary carotenoids in carotenogenic microalgae (Ben-Amotz \& Avron 1983, Boussiba, 2000). Concerning the effect of illumination cycles, the investigation by Kobayashi et al. (1992) showed that 24:0 L/D cycle was more effective than 12:12 L/D cycle for carotenoid formation under different light intensities $(68,139,210$ and $281 \mu \mathrm{mol} \mathrm{m}^{-2} \mathrm{~s}^{-1}$ ). It also indicated that illumination duration is more important than light intensity in carotenoid biosynthesis. For the physiological effects of spectral quality of light, Katsuda et al. (2006) reported that the higher cell density and astaxanthin concentration were obtained under blue flashing light of 2 to 12 $\mu \mathrm{mol} \mathrm{m} \mathrm{m}^{-2} \mathrm{~s}^{-1}$.

Lipid and astaxanthin were accumulated under stress conditions such as nitrogen starvation and specific spectral quality of light (Zhekisheva et al., 2002). To protect the cell from photo-inhibition, H. pluvialis developed a light protection mechanism to accumulate lipid and astaxanthin as an electron sink and shading pigments respectively (Saha, 2013). In this study, the experiment focused on the interaction of light-spectral composition, light intensity, illumination duration and illumination-darkness cycles for astaxanthin accumulation and evaluation on the cost of astaxanthin production.

\section{Materials and Methods}

\section{Microalgae culture}

The microalgae strain used in this study was $H$. pluvialis (UTEX\# 2505) obtained from the algae culture collection at the University of Texas, Austin, Texas, USA. All experiments were performed at a temperature controlled environment at $25 \pm$ $3^{\circ} \mathrm{C}$. The light was provided by a cool white LED light (T5 15W $6400 \mathrm{~K}$ ) during the experimental period.

\section{Experimental set-up}

H. pluvialis was cultivated for 12 days in a transparent square tank with 6-L of modified BG-11 medium (Rippka et al., 1979). The medium was sterilized using autoclave and $\mathrm{pH}$ adjusted to 7 - 8. Sterilized air was supplied by air pump (Hailea V-30) and a disposable syringe filter (ADVANTEC DISMIC-250CS, $0.45 \mu \mathrm{m}$ ). To determine the suitable light source and photoperiod for the best growth of $H$. pluvialis, 12: 12 and 24: $0 \mathrm{~L} / \mathrm{D}$ cycles were chosen under different illuminations that included white plasma light, red and blue light. The light intensity provided was $40.6 \pm 3.05 \mu \mathrm{mol} \mathrm{m}^{-2} \mathrm{~s}^{-1}$. The initial cell concentration of $H$. pluvialis was $1.08 \times 10^{4}$ cells $/ \mathrm{ml}$ for $24: 0$ and $12: 12$ L/D cycle.

\section{Analytical methods}

The "Phytoplankton Counting Techniques" (American Public Health Association, 1995) method was used to determine cell count (cells $/ \mathrm{ml}$ ) using Sedgewick-Rafter counting chambers through a light microscope. Algal biomass samples were filtered using a glass fiber filter (ADVANTEC type GC-50, $47 \mathrm{~mm}$ di- ameter, $0.45 \mu \mathrm{m})$. The dry weight of the algal sample was measured by drying the filter paper at $105^{\circ} \mathrm{C}$ for 24 hours. The initial and final weight of the filter paper was weighed by analytical balance (AND HR-200). The biomass content was calculated by microalgal dry weight produced per liter $(\mathrm{mg} / \mathrm{L})$. The specific growth rate $(\mu)$ at the exponential phase was calculated according to:

$\mu=\ln \left(x_{2} / x_{1}\right) /\left(t_{2}-t_{1}\right)$

where, $x_{2}$ and $x_{1}$ are the cell density (cells $\left./ \mathrm{ml}\right)$ at $t_{2}$ and $t_{1}$ (sample day), respectively.

For nutrient analysis, the samples were filtered through a glass fiber filter (ADVANTEC type GC-50, $47 \mathrm{~mm}$ diameter, $0.45 \mu \mathrm{m})$ and frozen at $-35^{\circ} \mathrm{C}$ for later analysis. On the day of nutrient analysis, the samples were thawed at room temperature. A UV-1800 spectrophotometer (Shimadzu) was used to measure the wavelength to analyze the nitrate concentration. Nitrate concentration $\left(\mathrm{NO}_{3}-\mathrm{-N}\right)$ was measured using the standard method for Nitrogen-Nitrate $\left(\mathrm{NO}_{3}-\mathrm{-N}\right)$, the ultraviolet spectrophoto metric screening method at $220 \mathrm{~nm}$ and $275 \mathrm{~nm}$ (American Public Health Association, 1998). The maximum theoretical and expected nitrate concentration was calculated and the filtered sample was diluted when necessary.

Total lipid content was determined by using Bligh and Dyer (1959) with modifications. H. pluvialis culture was isolated and freeze dried (labconco freezone 4.5). Approximately 0.05 $\mathrm{g}$ of freeze dried algal cells was used for lipid extraction. A mixture of $2 \mathrm{ml}$ chloroform and $2 \mathrm{ml}$ methanol (1:1) was used for lipid extraction (Bligh and Dyer, 1959). $2 \mathrm{ml}$ of $0.88 \%$ sodium chloride was added to the mixture to improve the performance of lipid extraction. The mixture was shaken vigorously and centrifuged at $5000 \mathrm{rpm}$ for 3 minutes. Methanol/water (top phase) and chloroform (bottom phase) were separated. The chloroform layer was further purified with sodium sulphate anhydrous powder and collected into the weighed beaker. The organic solvents inside were evaporated by flushing under high purified nitrogen gas. The remaining lipids were weighed. This provided the percentage of lipids in algal dry weight. Lipid productivity $(\mathrm{mg} / \mathrm{L})$ was calculated using the formula shown below:

Lipid content (\%) $x$ dry biomass $(\mathrm{mg} / \mathrm{L})$

Concentrated acid lysis was used for astaxanthin extraction (Kang \& Sim, 2008; Kobayashi et al., 1997). The total astaxanthin concentration accounted for $80 \%$ of total carotene. The total carotene concentration was measured with the wavelength of $450 \mathrm{~nm}$.Calculations were done as follows (Huang, 2008):

$\mathrm{C}_{\mathrm{x} . \mathrm{c}}=\mathrm{A}_{450} \times 10 / 2500 \times \mathrm{V} / \mathrm{V}_{0}$

$\mathrm{C}_{\mathrm{AX}}=\mathrm{C}_{\mathrm{x}, \mathrm{c}} \times 80 \%$

Where, $\mathrm{C}_{\mathrm{x} . \mathrm{c}}$ and $\mathrm{C}_{\mathrm{AX}}$ are total carotenoid content $(\mathrm{mg})$ andastaxanthin content $(\mathrm{mg})$ respectively; $\mathrm{V}$ and $\mathrm{V}_{0}$ are extracted volume $(\mathrm{mL})$ and original volume $(\mathrm{mL})$ respectively.

\section{Statistical analysis}

The data were expressed as means of \pm standard de- 
viation $(n=3)$. Statistical analysis was carried out using SPSS software (Version 21). The data were tested statistically using one-way analysis of variance (ANOVA) test and post-hoc Turkey's honestly significant difference (HSD) test. The significant level was set at $\mathrm{P}<0.05$.

\section{Results and Discussion}

\section{Growth of $\boldsymbol{H}$. pluvialis under different light sources and pho- toperiods}

Our results showed that the cell density and biomass growth of $H$. pluvialis was significantly varied $(\mathrm{P}<0.05)$ in red LED light, blue LED light and white plasma light sources under different photoperiods. Table 1 summarizes the effect of different light sources and different photoperiods on maximum cell density, specific growth rate, cell division rate and maximum biomass. Maximum cell density, highest specific growth rates and maximum biomass of $8.58 \pm 0.452 \times 10^{5}$ cells $/ \mathrm{m}, 0.365 \pm$ 0.004 day $^{-1}$ and $0.950 \pm 0.030$ was observed on the $24: 0 \mathrm{~L} / \mathrm{D}$ cycle with white light source. Compared the result of 24:0 L/D cycle to $12: 12 \mathrm{~L} / \mathrm{D}$ cycle, the latter resulted in a poor cell growth.

In the column without a common superscript letter is significantly different from each other $(p<0.05)$. As analyzed by one-way ANOVA, Post-Hoc Tests, Turkey HSD.

$H$. pluvialis autotrophic and undergoes cell division for cell growth. It obtains carbon from carbon dioxide in the atmosphere (by aeration). Microalgae possess chlorophyll, the green pigment which is essential for photosynthesis to generate energy from light. The photosynthetic process in microalgae is divided into two stages named as light reactions and dark reactions. In the light reactions, light is absorbed by pigments in chloroplast and converted into chemical energy. ATP and NADPH are formed through a photosynthetic electron transport chain. In dark reactions, which take place in the stroma, the chemical energy is stored in starch by fixing $\mathrm{CO}_{2}$ through the Calvin cycle (Boussiba, 2000; Imamoglu et al., 2007). Light energy was important for converting simple inorganic nutrients (nitrogen, phosphorus, oxygen) into protein, carbohydrate and lipid (Deas\& Orlob., 1999).
Therefore, the availability and optimization of light source are the main factors controlling productivity of the photosynthetic cultures. Maximum photosynthetic efficiencies can be achieved when the photoperiod approaches the photosynthetic unit (Wahidin et al., 2013). In this study, the light sources were from red LED light, blue LED light and white plasma light. They provide energy to transfer electrons from water to $H$. pluvialis 's NADP+, forming NADPH and generate ATP. Red LED light, blue LED light and white plasma light belong to visible light spectrum. The wavelengths of the visible light correspond to different photosynthetically active radiation and utilized in photosynthesis process (Koblizek et al., 2007). With reference to the result (Table 1), white plasma light is more effective for growth of cells than red and blue LED light. It is because white plasma is a visible light which consists of a spectrum ranging from the violet of about $380 \mathrm{~nm}$ to the red at $750 \mathrm{~nm}$. The white plasma covers both the absorption peaks at $430 \mathrm{~nm}$ and $662 \mathrm{~nm}$ of chlorophyll a. As more energy of photons is absorbed by photosynthetic pigments and transferred to the reaction center of $H$. pluvialis where it is utilized for photochemistry, it resulted in more chlorophyll a molecules are ionized. So more ATP and NADPH are generated for the synthesis of carbohydrates (Koblizek et al., 2007). In addition, Katsuda et al. (2004) showed that red LED light which operated at a relatively low light intensity was more suitable for cell growth than blue LED light. Red light provides a higher level of excitement in the chlorophyll electrons, so the effectiveness of these chlorophyll pigments increases significantly. These electrons produce water hydrolysis, which leads to the synthesis of ATP. Therefore, ATP is used for the synthesis of carbohydrates that advance the growth of Haematococcus sp. (Piippo et al., 2006; Pérez-Pazos \& Fernández-Izquierdo, 2011; Rosemond et al., 2000). The activation of the phytochrome by red LED light regulates the expression of some nuclear genes that produce chloroplastic proteins related to photosynthesis (Hill, 1996; Neff et al., 2000; Piippo, et al., 2006; Pérez-Pazos \& Fernández-Izquierdo, 2011; Rosemond, et al., 2000). Hence, red LED light was more effective for cell growth than blue one.

Table 1: Maximum cell density, specific growth rate and division rate of Haematococcus sp. under different light sources and different photoperiods.

\begin{tabular}{|c|l|c|c|c|}
\hline $\begin{array}{c}\text { Photoperiod } \\
\text { (L/D cycle) }\end{array}$ & Light source & $\begin{array}{c}\text { Maximum cell density } \\
(\mathbf{x ~ 1 0} \text { cells/ml) }\end{array}$ & $\begin{array}{c}\text { Specific growth rate } \\
\boldsymbol{\mu}\left(\mathbf{d a y}^{-1}\right)\end{array}$ & $\begin{array}{c}\text { Maximum biomass } \\
(\mathbf{g} / \mathbf{L})\end{array}$ \\
\hline \multirow{2}{*}{$24: 0$} & Red LED & $6.08 \pm 0.110$ & $0.336 \pm 0.002$ & $0.710 \pm 0.010$ \\
\cline { 2 - 5 } & Blue LED & $3.57 \pm 0.230^{\mathrm{a}}$ & $0.291 \pm 0.005^{\mathrm{a}}$ & $0.407 \pm 0.008^{\mathrm{a}}$ \\
\cline { 2 - 5 } & White Plasma & $8.58 \pm 0.452$ & $0.365 \pm 0.004$ & $0.950 \pm 0.030$ \\
\hline \multirow{2}{*}{$12: 12$} & Red LED & $3.45 \pm 0.155^{\mathrm{a}}$ & $0.289 \pm 0.004^{\mathrm{a}}$ & $0.360 \pm 0.018$ \\
\cline { 2 - 5 } & Blue LED & $1.28 \pm 0.212$ & $0.210 \pm 0.007$ & $0.132 \pm 0.008$ \\
\cline { 2 - 5 } & White Plasma & $4.05 \pm 0.338^{\mathrm{a}}$ & $0.304 \pm 0.004^{\mathrm{a}}$ & $0.420 \pm 0.010^{\mathrm{a}}$ \\
\hline
\end{tabular}

Data are given as mean \pm standard deviation of triplicate experimental culture. In the columns without a common superscript letter are significant differences to each other $(\mathrm{p}<0.05)$. As analyzed by one-way ANOVA, post hoc tests, Tukey HSD.

\section{Lipid and astaxanthin production in $\mathrm{H}$. pluvialis under different light sources and photoperiods}

To accumulate a higher content of astaxanthin, two-stage cultivation was carried out with (1) green stage for biomass production and (2) astaxanthin accumulation stage. The green $H$. pluvialis cells were harvested after 12-day growth phase and transferred to the environment with nitrogen deficiency and exposed to strong light intensity of $170 \pm 3 \mu \mathrm{mol} \mathrm{m} \mathrm{m}^{-2} \mathrm{~s}^{-1}$ with different wavelengths (white plasma, blue and red LED light) and photoperiods (24: 0 and 12:12 L/D cycle) for 3 days. After 3 days, lipid and astaxanthin contents increased in all experimental conditions. The statistical analysis showed that lipid and astaxanthin content of H. pluvialis are significantly difference in different light conditions and L/D cycles $(\mathrm{p}<0.05)$. 
In Table 2, it showed that the highest total lipid content was $0.055 \pm 0.002 \mathrm{~g} / \mathrm{L}$ with $5.270 \pm 0.139$ (percentage dry weight) in the white plasma light under 24:24 L/D cycle. Although the percentage of total lipid was higher in the white plasma light under12:12 L/D cycle, the lipid productivity was lower when exposed to $24: 24 \mathrm{~L} / \mathrm{D}$ cycle due to a higher amount of dry biomass production. Harwood (1998) reported that different photoperiods could change the lipid metabolism in microalgae which altered the composition of lipid profile. Photoperiod under 24:24 L/D cycle was considered as an optimal condition for lipid production in $H$. pluvialis. Under optimal growth condition, H. Pluvialis synthesized fatty acids principally for ester- ification into glycerol-based membrane lipids, which led to a higher growth rate. However, under stress condition (with nitrogen deprivation and high light intensity), $H$. pluvialis had an imbalanced oxide-reduction potential and high reduction power. So, the hydrogen ions were transferred to reserve organic compounds, such as lipids, in order to restore balance. Nitrogen starvation could promote the accumulation of total lipid in microalgae. Under nitrogen deficiency, algal growth was slowed down as there was no requirement for synthesizing a new cell membrane compounds. As a result, the cells divert and deposit fatty acids into triacylglycerol (TAG) (Sharma et al., 2012).

Table 2: Maximum lipid content and astaxanthin content under different light sources and photoperiods.

\begin{tabular}{|c|c|c|c|c|c|c|}
\hline $\begin{array}{l}\text { Photoperiod } \\
\text { (L/D cycle) }\end{array}$ & Light source & $\begin{array}{l}\text { Drybiomass after } \\
3 \text { days condition } \\
\text { change }(g / L)\end{array}$ & $\begin{array}{l}\text { Lipid content } \\
\text { (g/L) }\end{array}$ & $\begin{array}{l}\text { Lipid content } \\
\text { (\% dry weight) }\end{array}$ & $\begin{array}{l}\text { Astaxanthin } \\
\text { content }(g / L)\end{array}$ & $\begin{array}{l}\text { Astaxanthin } \\
\text { content( } \%)\end{array}$ \\
\hline \multirow{3}{*}{$24: 0$} & Red LED & $0.830 \pm 0.013$ & $0.042 \pm 0.001^{\mathrm{a}}$ & $5.027 \pm 0.080^{\mathrm{a}}$ & $0.023 \pm 0.000^{\mathrm{a}}$ & $2.830 \pm 0.046^{\mathrm{a}}$ \\
\hline & Blue LED & $0.462 \pm 0.015^{\mathrm{a}}$ & $0.030 \pm 0.002$ & $6.577 \pm 0.168$ & $0.025 \pm 0.001^{\mathrm{a}}$ & $5.513 \pm 0.114$ \\
\hline & White Plasma & $1.037 \pm 0.008$ & $0.055 \pm 0.002$ & $5.270 \pm 0.139^{\mathrm{a}}$ & $0.049 \pm 0.001$ & $4.757 \pm 0.080^{b}$ \\
\hline \multirow{3}{*}{$12: 12$} & Red LED & $0.418 \pm 0.012$ & $0.019 \pm 0.000$ & $4.560 \pm 0.092$ & $0.011 \pm 0.000^{b}$ & $2.597 \pm 0.021^{\mathrm{a}}$ \\
\hline & Blue LED & $0.192 \pm 0.006$ & $0.015 \pm 0.000$ & $7.740 \pm 0.056$ & $0.009 \pm 0.000^{b}$ & $4.903 \pm 0.057^{b}$ \\
\hline & White Plasma & $0.478 \pm 0.015^{\mathrm{a}}$ & $0.043 \pm 0.002^{\mathrm{a}}$ & $8.923 \pm 0.186$ & $0.017 \pm 0.000$ & $3.543 \pm 0.168$ \\
\hline
\end{tabular}

Data are given as mean \pm standard deviation of triplicate experimental culture. In the columns without a common superscript letter are significant differences to each other $(\mathrm{p}<0.05)$. As analyzed by one-way ANOVA, post hoc tests, Tukey HSD.

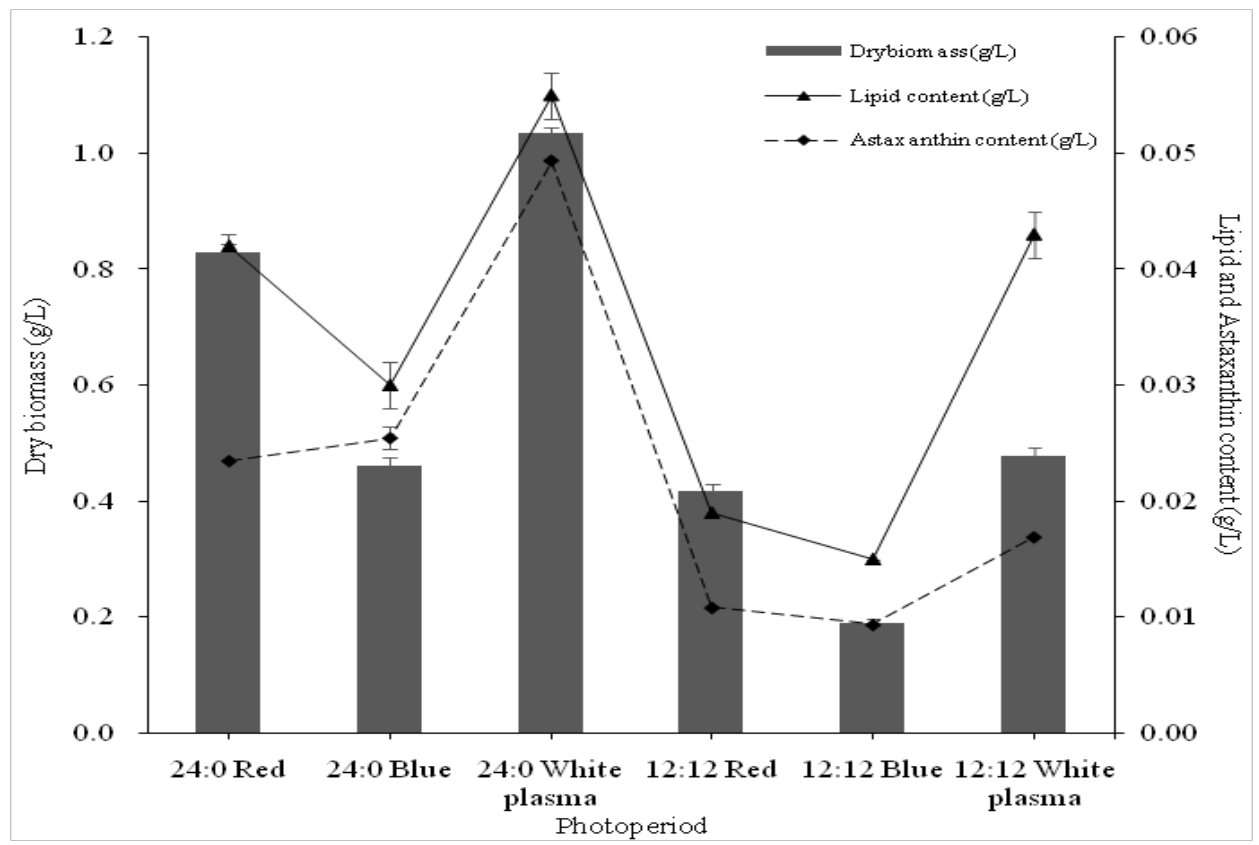

Figure 1: Astaxanthin content of $H$. pluvialis at three different light sources under two different photoperiods (24:0 and 12:12 L/D cycle) after 3 days culture condition change. Data are represented as mean \pm standard deviation $(n=3)$.

The highest astaxanthin content was $0.049 \pm 0.001 \mathrm{~g} / \mathrm{L}$ with $4.757 \pm 0.080$ (percentage dry weight) under white plasma light of 24:0 L/Dcycle (Figure 1). The highest cell astaxanthin percentage was observed in blue LED light of 24:0 L/D cycle (Table 2). Katsuda et al. (2004) reported that LED light emitting short wavelengths $(380-470 \mathrm{~nm})$ could induce the morphological change of $H$. pluvialis and enhanced the astaxanthin accumulation. Juneja et al. (2013) also reported that the energy content of blue light $(400-480 \mathrm{~nm})$ was greater than that of red light $(620-750 \mathrm{~nm})$, thus few photons of blue light were required to achieve an equivalent magnitude of energy intensity using red light. However, the productivity of astaxanthin is based on the biomass production. White plasma lights induced a higher biomass production, which could overcome the lower percentage of cell astaxanthin when compared to blue LED light. In H. pluvialis, astaxanthin appeared mostly as mono- and di-esters of various fatty acids and constitutes up to $95 \%$ of total secondary carotenoids in the cells (Lee \& Zhang, 1999). These pigments were presented in lipid globules outside the chloroplast (Grünewald \& Hagen, 2001; Sun et al., 1998). Moreover, the accumulation of astaxanthin was related to the biosynthesis of fatty acid. During the process, oleic acid combined with TAG and became a ma- 
jor constituent of cytoplasmic lipid droplets (LD) (Zhekisheva et al., 2002). This class of neutral lipids formed the intracellular depot for astaxanthin accumulation. Fatty acids were used for esterification of polar hydroxyl groups of astaxanthin prior to its deposition within the hydrophobic environment of LD. Zhekisheva et al. (2005) stated that cultivation stress induced cytoplasmic accumulation of secondary carotenoid (astaxanthin) within microalgae cells. It explained how the light and nutrient stress stimulated the accumulation of lipids and astaxanthin synthesis in $H$. pluvialis.

In the column without a common superscript letter is significantly different from each other $(p<0.05)$. As analyzed by one-way ANOVA, Post-Hoc Tests, Turkey HSD.
For lipid and astaxanthin production in this experiment (with 12-day biomass cultivation and 3-day stress condition), the electrical charge is 0.987 dollars for $1 \mathrm{kwh}$ in Hong Kong. The total energy consumption, energy charge and energy cost for lipid and astaxanthin production was shown in Table 3 . The white plasma light consumed more energy than the blue and red LED light under 12:12 and 24: $0 \mathrm{~L} / \mathrm{D}$ cycles and the energy cost was the highest when white plasma light was used. So, the production of $1 \mathrm{~g}$ of lipid and astaxanthin with 24: $0 \mathrm{~L} / \mathrm{D}$ red LED light condition was the most cost effective.

In the column without a common superscript letter is significantly different from each other $(p<0.05)$. As analyzed by one-way ANOVA, Post-Hoc Tests, Turkey HSD.

Table 3: Total energy consumption, energy charge, cost of lipid astaxanthin production under different conditions.

\begin{tabular}{|c|l|c|c|c|c|}
\hline $\begin{array}{l}\text { Photoperiod } \\
\text { (Light: Dark) }\end{array}$ & Light source & $\begin{array}{l}\text { Total energy consumption } \\
\text { (kWh) }\end{array}$ & $\begin{array}{l}\text { Energy charge } \\
\text { (HKD) }\end{array}$ & $\begin{array}{l}\text { Energy cost for producing } \\
\text { 1 g of lipid (HKD) }\end{array}$ & $\begin{array}{l}\text { Energy cost for producing } \\
\text { 1 g of astaxanthin (HKD) }\end{array}$ \\
\hline $24: 0$ & Red LED & 3.58 & 1.92 & 14.03 & 25.08 \\
\hline $24: 0$ & Blue LED & 8.62 & 4.62 & 47.27 & 55.69 \\
\hline $24: 0$ & White Plasma & 31.70 & 16.98 & 94.81 & 105.74 \\
\hline $12: 12$ & Red LED & 1.79 & 0.959 & 15.50 & 27.12 \\
\hline $12: 12$ & Blue LED & 4.31 & 2.31 & 47.27 & 75.43 \\
\hline $12: 12$ & White Plasma & 15.85 & 8.49 & 60.63 & 153.98 \\
\hline
\end{tabular}

Data are given as mean \pm standard deviation of triplicate experimental culture.

\section{Conclusions}

This study described the favorable conditions for lipid and astaxanthin production with $H$. pluvialis under low light intensity and then high light intensity with nitrogen deprivation condition. The results indicated that white plasma light with 24:0 L/D cycle was the best condition for cell growth, lipid and astaxanthin production. The red LED light generally had the lowest energy consumption. The lowest production cost for producing $1 \mathrm{~g}$ of lipid and astaxanthin was under red LED light with 24:0L/D cycle. The results were significant for commercial production of astaxanthin.

Acknowledgements: The work described in this paper was fully supported by the Open University of Hong Kong Research (PACRD) Funding (No. 2015/1.10). Besides, this work was also supported by a grant from the Research Grants Council of the Hong Kong Special Administrative Region, China (UGC/ IDS16/14)

\section{References}

1). Lorenz RT, Cysewski GR. Commercial potential for Haematococcus microalgae as a natural source of astaxanthin. (2000) Trends Biotechnol 18(4): S160-S167.

2). Miki, W. Biological functions and activities of animal carotenoids. (1991) Pure and Applied Chemistry 63: S141-S146.

3). Capelli, B., Bagchi, D., Cysewski, G. Synthetic Astaxanthin is significantly inferior to algal-based Astaxanthin as an antioxidant and may not be suitable as a human nutritional supplement. (2013) NutraFoods 12: S145-S152.

4). Orosa M, Franqueira D, Cid A, Abalde J. Carotenoid accumulation in Haematococcus pluvialis in mixotrophic growth. (2001) Biotechnol. Lett. 23: S373-S378.
5). John, M.H., Osborn, A. Culture of the astaxanthin-producing green alga Haematococcus pluvialis 1. Effects of nutrients on growth and cell type. (1991) J. Appl. Phycol. 3: S295-S304.

6). Boussiba S., Vonshak A. Astaxanthin accumulation in the green alga Haematococcus pluvialis. (1991) Plant Cell Physiol. 32: S1077-S1082. 7). Fábregas, J., Otero, A., Maseda, A., Domínguez, A. Two-stage cultures for the production of astaxanthin from Haematococcus pluvialis. (2001) J. Biotechnol. 89(1): S65-S71.

8). Sarada, R., Tripathi, U., Ravishankar, G. Influence of stress on astaxanthin production in Haematococcus pluvialis grown under different culture conditions. (2002) Process Biochemistry 37(6): S623-S627.

9). Tripathi, U., Sarada, R., Ravishankar, G. Effect of culture conditions on growth of green alga-Haematococcus pluvialis and astaxanthin production. (2002) Acta Physiol. Plant. 24(3): S323-S329.

10). Boussiba S. Carotenogensis in the green alga Haematococcus pluvialis: cellular physiology and stress response. (2000) Physiol. Plant. 108(2): S111-S117.

11). Domínguez-Bocanegra, A. R., Ponce-Noyola, T., Torres-Muñoz, J. A. Astaxanthin production by Phaffia rhodozyma and Haematococcus pluvialis: a comparative study. (2007) Appl. Microbiol. Biotechnol. 75(4): S783-S791.

12). Giannelli, L., Yamada, H., Katsuda, T., Yamaji, H. Effects of temperature on the astaxanthin productivity and light harvesting characteristics of the green alga Haematococcus pluvialis. (2015) J. biosci. Bioeng. 119(3): S345-S350.

13). Ben-Amotz, A., Avron, M. On the factor which determine massive beta-carotene accumulation in the halotolerant alga Dunaliella bardawil. (1983) Plant Physiol. 72(3): S593-597.

14). Kobayashi, M., Kakizono, T., Nishio, N., Nagai, S. Effects of light intensity, light quality, and illumination cycle on astaxanthin formation in a green alga, Haematococcus pluvialis. (1992) J. Ferment. Bioeng. 74(1): S61-S63.

15). Katsuda, T., Shimahara, K., Shiraishi, H., Yamagami, K., Ranjbar, R., Katoh, S. Effect of flashing light from blue light emitting diodes on cell growth and astaxanthin production of Haematococcus pluvialis. (2006) J. Biosci. Bioeng. 102(5): S442-S446. 
16). Zhekisheva, M., Boussiba, S., Khozin-Goldberg, I., Zarka, A., Cohen, Z. Accumulation of oleic acid in Haematococcus pluvialis (Chlorophyceae) under nitrogen starvation or high light is correlated with that of astaxanthin esters. (2002) J. Phycol. 38(2): S325-S331.

17). Saha, S. K., McHugh, E., Hayes, J., Moane, S., Walsh, D., Murray, P. Effect of various stress-regulatory factors on biomass and lipid production in microalga Haematococcus pluvialis. (2013) Bioresour. Technol. 128: S118-S124.

18). Rippka, R., Deruelles, J., Waterbury, J. B., Herdman, M., Stanier, R. Y. Generic assignments, strain histories and properties of pure cultures of cyanobacteria. (1979) J. Gen. Microbiol. 111(1): S1-S61.

19). American Public Health Association, America Water Works. 10200 F. Phytoplankton Counting Techniques. (1995) Washington, DC, USA. 20). American Public Health Association, America Water Works. Standard methods for the examination of water and wastewater. NO3- spectrophotometric screening method. (1998) Washington, DC, USA.

21). Bligh, E. G., Dyer, W. J. A rapid method of total lipid extraction and purification. (1959) Can. J. Biochem. Physiol. 37(8): S911-S917.

22). Kang, C. D., Sim, S. J. Direct extraction of astaxanthin from Haematococcus culture using vegetable oils. (2008) Biotechnol. Lett. 30(3): S441-S444.

23). Kobayashi, M., Kurimura, Y., Sakamoto, Y., Tsuji, Y. Selective extraction of astaxanthin and chlorophyll from the green alga Haematococcus pluvialis. (1997) Biotechnol. Tech. 11(9): S657-S660.

24). Huang, S.Y. Studies on Haematococcus Pluvialis Culture Methods and Extraction, Stability and Application of Astaxanthin. (2008).

25). Imamoglu, E., Sukan, F. V., Dalay, M. C. Effect of different culture media and light intensities on growth of Haematococcus pluvialis. (2007) Internatl. J. Nat. Eng. Sci. 1(3): S5-S9.

26). Deas, M., Orlob, G. Klamath River Modeling Project. (1999).

27). Koblizek, M., Torzillo, G. Photosynthesis in Microalgae (2007).

28). Katsuda, T., Lababpour, A., Shimahara, K., Katoh, S. Astaxanthin production by Haematococcus pluvialis under illumination with LEDs. (2004) Enz. Micro. Tech. 35(1): S81-S86.

29). Piippo, M., Allahverdiyeva, Y., Paakkarinen, V., et. al. Chloroplast-mediated regulation of nuclear genes in Arabidopsis thaliana in the absence of light stress. (2006) Physiol. Genomics 25(1): S142-S152. 30). Pérez-Pazos, J. V., Jazmín-Vanessa, Fernández-Izquierdo, P. Synthesis of neutral lipids in Chlorella sp. under different light and carbonate conditions. (2011) CT\&F-Ciencia, Tecnología y Futuro 4(4): S47-S58.
31). Rosemond, A. D., Mulholland, P. J., Brawley, S. H. Seasonally shifting limitation of stream periphyton: response of algal populations and assemblage biomass and productivity to variation in light, nutrients, and herbivores. (2000) Can. J. Fisheries and Aq. Sci. 57(1): S66-S75.

32). Hill, W. Algal ecology: freshwater benthic ecosystems. (1996) Effects of light S121-S148.

33). Neff, M. M., Fankhauser, C., Chory, J. Light: an indicator of time and place. (2000) Genes Dev. 14 (3): S257-S271.

34). Rosemond, A. D., Mulholland, P. J., Brawley, S. H. Seasonally shifting limitation of stream periphyton: response of algal populations and assemblage biomass and productivity to variation in light, nutrients, and herbivores. (2000) Can. J. Fisheries and Aq. Sci. 57(1): S66-S75.

35). Juneja, A., Ceballos, R., Murthy, G. Effects of Environmental Factors and Nutrient Availability on the Biochemical Composition of Algae for Biofuels Production: A Review. (2013) Energies 6(9): S4607-S4638. 36). Harwood, J.L. (1998) Membrane lipids in algae. In Lipids in Photosynthesis: Structure, Function and Genetics (Siegenthaler, P.A. and Murata, N., eds). Dordrecht, The Netherlands: Kluwer Academic Publishers 53-64.

37). Sharma, K. K., Schuhmann, H., Schenk, P. M. High Lipid Induction in Microalgae for Biodiesel Production. (2012) Energies 5(5): S1532-S1553.

38). Lee, Y. K., Zhang, D. H. (1999). Production of astaxanthin by Haematococcus. In: Cohen Z, ed. Chemicals from Microalgae. Taylor and Francis, London. 175-195.

39). Grünewald, K., Hagen, C. $\beta$-carotene is the intermediate exported from the chloroplast during accumulation of secondary carotenoids in Haematococcus pluvialis. (2001) J. Appl. Phycol. 13(1): S89-S93.

40). Sun, Z., Cunningham, F., Gantt, E. Differential expression of two isopentenyl pyrophosphate isomerases and enhanced carotenoid accumulation in a unicellular chlorophyte. (1998) Proc. Natl. Acad. Sci. 95(19): S11482-S11488.

41). Zhekisheva, M., Boussiba, S., Khozin-Goldberg, I., et al. Accumulation of oleic acid in Haematococcus pluvialis (Chlorophyceae) under nitrogen starvation or high light is correlated with that of astaxanthin esters. (2002) J Phycol 38(2): S325-S331.

42). Zhekisheva, M., Zarka, A., Khozin-Goldberg, I., et al. Inhibition of astaxanthin synthesis under high irradiance does not abolishtriacylglycerol accumulation in the green alga Haematococcus pluviali (Chlorophyceae). (2005) J Phycol 41: 819-826.

\section{Ommega Online Publishers}

Journal Title: Journal of Marine Biology and Aquaculture Journal Short Name: J Marine Biol Aquacult
Journal ISSN 2381-0750

E-mail: marinelife@ommegaonline.org

Website: www.ommegaonline.org 